\title{
DAYLIGHT INVESTIGATION IN CAMPUS LECTURE THEATERS. CASE STUDY: SOUTH WEST COAST UNIVERSITY OF NIGERIA
}

\author{
OYELEYE OLAYINKA*1, MAKANJU TOLULOPE ${ }^{1}$ \\ ${ }^{1}$ Federal University of Technology, Akure, Ondo State, P. M. B 704, Nigeria
}

\begin{abstract}
Appropriate day lighting design saves lighting power energy (LPE) and reduces LPE cost. This research investigates daylight contribution of in selected north campus lecture theaters in a South West Coast University of Nigeria. TES 1332A lux meter was used for lux level determination. The window area to wall area $\left(A_{W D}\right.$ to $\left.A_{W}\right)$ ratio was determined using reliable algorithms. In the three studied buildings, the daylight contribution varies from 12 lux to 3803 lux; $A_{W D}$ to $A_{W}$ varies from $14 \%$ to $22 \%$ to $37 \% ; 22 \% A_{W D}$ to $A_{W}$ is considered moderate while $37 \% A_{W D}$ to $A_{W}$ is considered more suitable in the studied buildings.
\end{abstract}

Keywords: daylight, room index, lecture theatre, lux level, window area to wall area

\section{INTRODUCTION}

Daylight is a significant, comfortable, and natural energy that contribute to passive solar building design [1]. Daylight varies in luminosity [2]. Appropriate day lighting design saves lighting power energy [3]. Sun is example of daylight emitting energy for about 4.5 Giga years [4]. According to [5-6] the use of daylight energy in illumination of commercial building reduces artificial energy demand and greenhouse effect. Electric lighting energy utilization in buildings is $40-50 \%$ of the total energy cost [5-6]. Utilize daylight in building facilitates low lighting cost. Natural light is a free energy resource. A proper incorporation of daylight through distribution of top lights on either side or on top of building can reduce the electrical lighting consumption [7]. Day lighting is the use of sunlight to reduce the use of electric lighting [1].

Buildings that utilize daylight with lighting control system to maintain light level in the interior space are estimated to reduce electric lighting energy consumption by $50-80 \%$ [5]. Students using daylight in schools enjoy health benefits [8-9].

Windows choice for buildings is very important, in term of materials, transparency, thickness, and window area has an impact on contribution of daylight [10]. Introducing natural light into buildings will saves energy and creates an improve environment and ability to know the sky situation. Proper day lighting in buildings embraces good lighting distribution, avoidance of excess brightness, sky illumination, building location, internal space arrangement nature of interior materials and shading materials. The consideration of daylight with combination of design factors will help to design energy at low cost and improve environment healthily [9]. These design factors are related to biological and behavioral factors [11]. Lighting simulation analysis, use of computer lighting software to generate lux level, and field survey established that day lighting can give extensive savings in energy from 30 to 70 percent of electrical light consumption [12].

Studies from different regions and climates accounted for lighting power reduction using daylight [12-16]. However, most of the electrical energy use in illumination is produced by non-renewable energy resources of

\footnotetext{
*Corresponding author, email: mooyeleye@,futa.edu.ng
}

(C) 2021 Alma Mater Publishing House 
burning fossil fuels. This non-renewable energy source is characterized by higher price and negative impacts on the environment. Provision of daylight need to be incorporated in lighting design due to the benefits $[6,13]$.

Evaluation of daylight were carried out in library using computer simulation, Zaria, Kaduna State, North West Nigeria and lecture theaters (LT) using daylight factor, lux level measurement Makurdi, Benue State, North Central, Nigeria, and offices, Akure, Ondo State, South West Nigeria [17-19]. Similarly, investigation of daylight contributions in selected north campus lecture theaters, Federal University of Technology Akure, Ondo state Nigeria, a University in South West Coast of Nigeria, Figure 1 to 3, researched to in this work using window to wall ratio and lux level measurement.

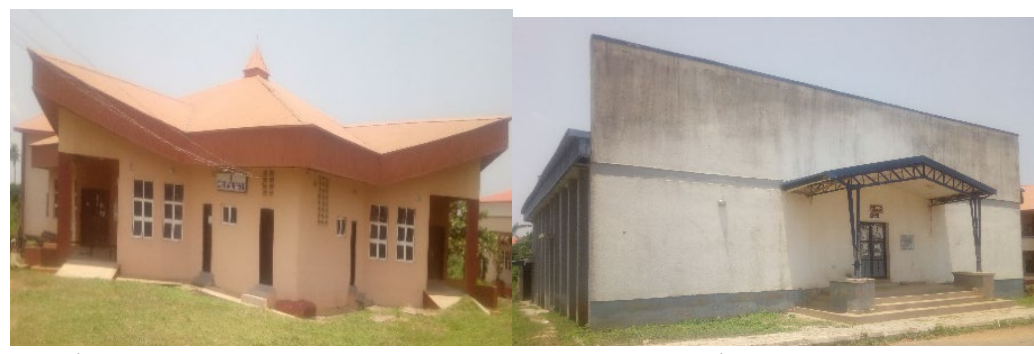

Fig. 1. 1000 Seat LT.

Fig. 2. FBN LT.

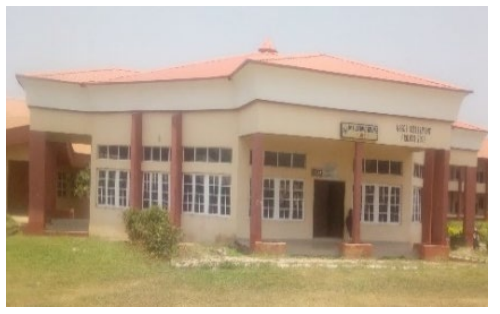

Fig. 3. 3-In-1 LT.

\subsection{Optimization of daylight usage}

Daylight is a renewable source of energy that illuminate the earth surface. According to [20] daylighting quality will improve good luminance in buildings and facilitate optimal design. Combined day and artificial lights are useful in museum for required color appearance. Suitable application of daylight in design will pave way for visual wellbeing in hall.

This suitable application will reduce power consumption and greenhouse undesirable effect [21-22]. Proper sizing of windows is necessary to reduce glare in edifice for the facilitation of the daylight optimization. Otherwise, glare may result [23].

\subsection{Natural light contribution and passive design}

Passive design is a function of using natural energy for required comfort, it is popular nowadays [24-25]. The major source of electricity production for mechanical equipment operation accounts to the increase in greenhouse negative effect of global warming [6]. It is also characterized by higher cost in comparison with natural lighting.

\subsection{Light energy sources}

Light energy sources are sources of light production. The sources of light can either be natural or artificial source. Sources of light differ in how they provide energy to the charged particles. Incandescent light comes from heat source while luminescent light comes from chemical or electric energy source [26].

The article [27] revealed that energy savings can be maximized by utilizing daylight source of energy in lighting design for classrooms, libraries, lecture theaters and offices buildings that are mainly occupied during the day.

Table 1 compared the artificial and natural sources of light in buildings noting the merits and demerits $[6,28]$.

\subsection{Side effects of daylight energy source}

[29] noted that the principal problem with daylight is the associated heat. During the hot season the associated heat cooling may be a problem. In order to enjoy daylight problem of the associated heat need to be control [30].

Glare is another challenge with daylight. It is defined as unwanted ray of light to the eyes and affects productivity negatively. Good daylight design can control this effect.

Table 1. Comparison between natural and artificial light $[6,28]$.

\begin{tabular}{|l|l|l|}
\hline S/N & \multicolumn{1}{|c|}{ Natural } & \multicolumn{1}{c|}{ Artificial } \\
\hline 1 & They are produced naturally by the sun. & Man-made. \\
\hline 2 & $\begin{array}{l}\text { It is freely and abundantly supply with high } \\
\text { light source efficiency. }\end{array}$ & $\begin{array}{l}\text { It is not freely and abundantly supply coupled with } \\
\text { low light source efficiency. }\end{array}$ \\
\hline
\end{tabular}




\begin{tabular}{|l|l|l|}
\hline 3 & $\begin{array}{l}\text { Available during daytime and varies in } \\
\text { brightness at different seasons. }\end{array}$ & $\begin{array}{l}\text { May be available when needed through the day and } \\
\text { night and no variation }\end{array}$ \\
\hline 4 & Propagate through walls and roof aperture & Transmitted through electrical bulbs \\
\hline 5 & Renewable and benefits to the environment. & Non- renewable and source of greenhouse gases. \\
\hline
\end{tabular}

\subsection{Sky data}

According to [29], for effective and efficient daylight design, there must be enough of the day light. [28] reported the existence of three types of sky namely overcast (Figure 4), clear (Figure 5) and partly cloudy sky (Figure 6).

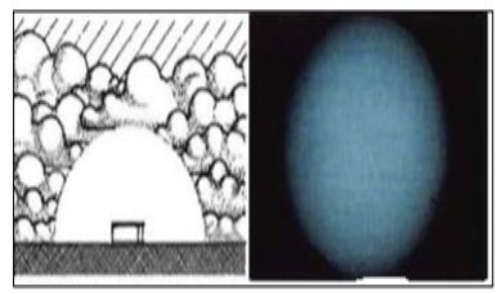

Fig. 4. Overcast Sky.

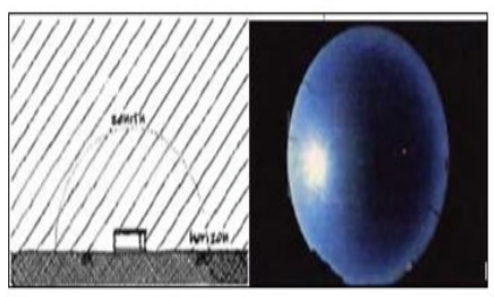

Fig. 5. Clear Sky.

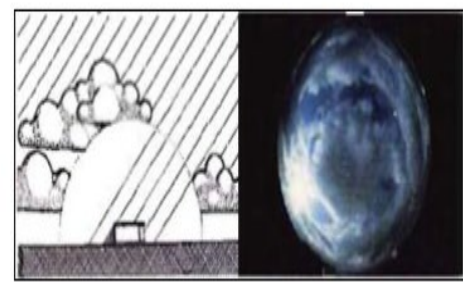

Fig. 6. Partly Cloudy Sky.

The daylight availability is mainly influenced by the luminance levels and patterns of the sky conditions. Lighting intensity from a sky is averagely constant throughout the day [28]. This intensity varies depending on the position of the sun [31].

The partly cloudy sky is the most common type of sky condition. The study area is overcast during wet season and partly cloudy during dry season [32]. It follows that type of sky condition should match lighting design.

\section{EXPERIMENTAL SETUP}

\subsection{Climatic condition of the study area}

Ondo State is in the south western part of Nigeria on latitude $6.9^{\circ} \mathrm{N}$ and longitude $5.1^{\circ} \mathrm{E}$. Akure is on approximated latitude, $7.3^{\circ} \mathrm{N}$ and longitude, $5.2^{\circ} \mathrm{E}$ [32]. During wet season, the state is warm and overcast. In dry season is hot and partly cloudy. The hotness normally varies from $18.3{ }^{\circ} \mathrm{C}$ to $35.6{ }^{\circ} \mathrm{C}$ [32]. It is deduced in this study that day light illuminance is directly proportional to the sky view.

\subsection{Room index}

Room Index is used to consider the room proportions and height of the luminaire above the working plan [33]. It is also used to determine the minimum number of measuring position of illumination level of a building as presented in Table $2[18,34]$.

Table 2. Room index and minimum number of measuring positions [18, 34].

\begin{tabular}{|c|c|c|}
\hline $\mathrm{S} / \mathrm{N}$ & Room index value & Minimum number of measuring positions \\
\hline 1 & $<1$ & 4 \\
\hline 2 & $1-1.9$ & 9 \\
\hline 3 & $2-2.9$ & 16 \\
\hline 4 & $\geq 3$ & 25 \\
\hline
\end{tabular}

\subsection{Data collection}

Data were collected using measuring tape and digital lux meters. The measurements were taken under different condition of the day -morning (8-9 am), afternoon (12-1 pm) and evening (5-6 pm) due to the usage of the lecture theatres.

Measuring Tape (Figure 7) and a reliable lux meter (Figure 8) previously used on a past research were used for dimensional measurement and lux level value determination in the study buildings respectively for reliability. 


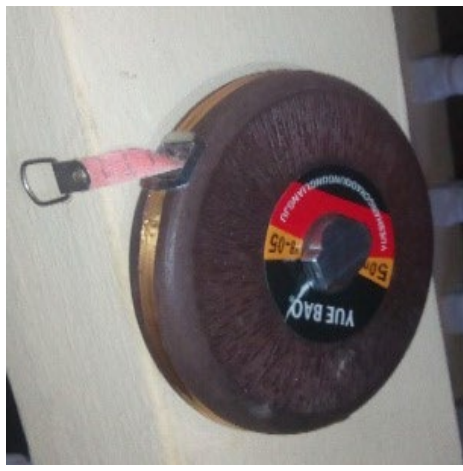

Fig. 7. Measuring Tape.

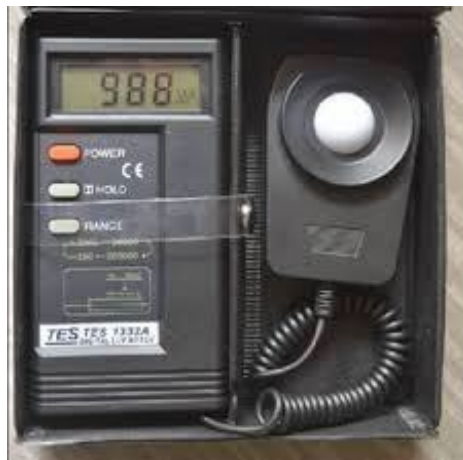

Fig. 8. TES 1332A Lux Meter.

2.4. Determination of window area $\left(\mathrm{A}_{W D}\right)$ to wall area $\left(A_{W}\right)$ ratio

Equation (1) to (4) were used to calculate $A_{W D}$; window area and wall area $\left(A_{W D+W}\right) ; A_{W}$; and window to wall area ratio( WWAR) respectively.

$$
A_{W D}=\sum_{w=1}^{n} L_{w} X B_{w}
$$

where Lw is the length of the window, $B_{w}$ is the breadth of the window, $w$ is the first number of window and $n$ is the last number of the window.

$$
A_{W D+W}=\sum_{i=1}^{n} L_{i} X B_{i}
$$

where $A_{W D+W}$ is the total wall area plus window, $\mathrm{i}$ is the first number of sections a building was divided into, Lis the length of each section, $\mathrm{B}$ is the breadth of each section and $\mathrm{n}$ is the last section of the building.

$$
A_{W}=A_{W D+W}-A_{W D}
$$

where $A_{W}$ is the area of wall.

Equation (4) was used to determine window to wall area ratio (WWAR).

$$
\mathrm{WWAR}=\frac{A_{W D}}{A_{W}} \times 100
$$

\subsection{Determination of interior average illumination of the lecture theater}

Two methods namely room index and random method were used to determine the average illumination of each lecture theaters. Equation (5) was used to determine the room index, RI, [18, 34] and equation 6 for random method.

$$
R I=\frac{L X W}{H_{m} X(L+W)}
$$

where Lis the internal length of the building, $\mathrm{W}$ is the width, and $\mathrm{H}_{\mathrm{m}}$ is the height.

$$
8 \leq R \leq 11 \text { points }
$$

where $\mathrm{R}$ is the measuring points based on the longest length of the buildings in consideration.

\section{RESULTS AND DISCUSSION}

Results of the research are presented in Tables 3 to 7 and Figures 9 and 10. 

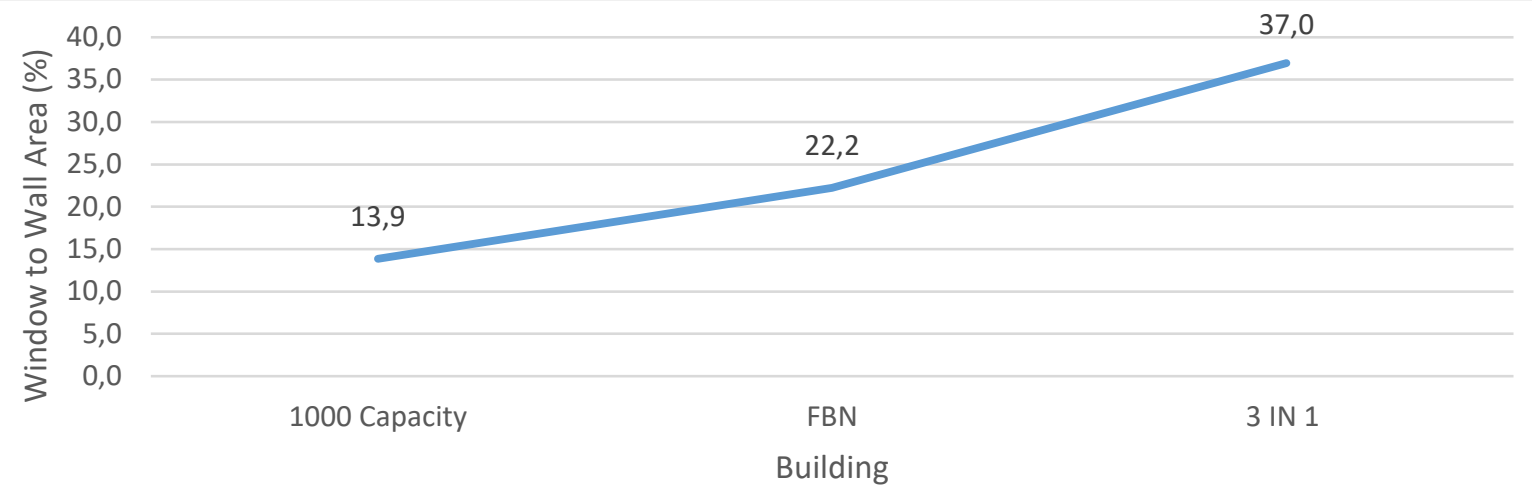

Fig. 9. Window to Wall Area Ratio.

Table 3. Room index and corresponding position.

\begin{tabular}{|c|c|c|}
\hline Buildings & Room index & Minimum measuring position \\
\hline 3 in 1 & 7.9 & 25 \\
\hline FBN & 7.2 & 25 \\
\hline $1000 \mathrm{LT}$ & 15.7 & 25 \\
\hline
\end{tabular}

Table 4. Random method measuring points.

\begin{tabular}{|c|c|}
\hline Buildings & Minimum measuring position \\
\hline 3 in 1 & 9 \\
\hline FBN & 8 \\
\hline 1000 LT & 11 \\
\hline
\end{tabular}

Table 5. Minimum and maximum lux level in the buildings.

\begin{tabular}{|c|c|c|c|c|c|c|}
\hline \multirow{3}{*}{ Building } & \multicolumn{3}{|c|}{ Minimum lux level } & \multicolumn{3}{c|}{ Maximum lux level } \\
\cline { 2 - 7 } & $\begin{array}{c}\text { Morning } \\
(8-9 \mathrm{am})\end{array}$ & $\begin{array}{c}\text { Afternoon } \\
(12-1 \mathrm{pm})\end{array}$ & $\begin{array}{c}\text { Evening } \\
(5-6 \mathrm{pm})\end{array}$ & $\begin{array}{c}\text { Morning } \\
(8-9 \mathrm{am})\end{array}$ & $\begin{array}{c}\text { Afternoon } \\
(12-1 \mathrm{pm})\end{array}$ & $\begin{array}{c}\text { Evening } \\
(5-6 \mathrm{pm})\end{array}$ \\
\hline 3-in-1 & 28 & 42 & 43 & 1472 & 3410 & 3803 \\
\hline FBN & 21 & 45 & 43 & 384 & 954 & 433 \\
\hline 1000 Capacity & 11.5 & 15 & 12 & 225 & 462 & 457 \\
\hline
\end{tabular}

Table 6 presents 3150 lux samples in daily average.

Table 6. Daily daylight contribution for each building using room index method.

\begin{tabular}{|c|c|c|c|c|c|c|c|}
\hline \multirow{3}{*}{ Building } & \multirow{2}{*}{ Day } & \multicolumn{2}{|c|}{ Morning average lux level } & \multicolumn{2}{c|}{ Afternoon average lux level } & \multicolumn{2}{c|}{ Evening average lux level } \\
\cline { 3 - 8 } & & Window closed & $\begin{array}{c}\text { Window } \\
\text { open }\end{array}$ & Window closed & $\begin{array}{c}\text { Window } \\
\text { open }\end{array}$ & $\begin{array}{c}\text { Window } \\
\text { closed }\end{array}$ & $\begin{array}{c}\text { Window } \\
\text { open }\end{array}$ \\
\hline \multirow{6}{*}{ 3-In-1 } & 1 & 230.8 & 449.4 & 291.8 & 612.7 & 317.0 & 626.7 \\
\cline { 2 - 8 } & 2 & 191.8 & 398.3 & 520.0 & 883.4 & 329.0 & 641.6 \\
\cline { 2 - 8 } & 3 & 126.6 & 233.7 & 470.0 & 816.7 & 350.0 & 644.6 \\
\cline { 2 - 8 } & 4 & 113.4 & 239.1 & 420.0 & 683.7 & 279.0 & 541.6 \\
\cline { 2 - 8 } & 5 & 235.2 & 493.9 & 447.0 & 674.0 & 219.9 & 461.7 \\
\cline { 2 - 8 } & 6 & 144.2 & 302.9 & 792.6 & 1351.8 & 489.7 & 1028.5 \\
\hline & 7 & 223.8 & 422.2 & 490.2 & 837.1 & 330.8 & 657.5 \\
\hline \multirow{5}{*}{ FBN } & 1 & 81.2 & 146.8 & 162.8 & 355.4 & 74.9 & 189.2 \\
\cline { 2 - 8 } & 2 & 101.2 & 168.8 & 177.8 & 379.4 & 60.4 & 177.2 \\
\cline { 2 - 8 } & 3 & 131.2 & 187.2 & 194.8 & 349.0 & 97.4 & 198.2 \\
\cline { 2 - 8 } & 4 & 106.7 & 170.3 & 203.1 & 360.2 & 85.4 & 188.4 \\
\cline { 2 - 8 } & 5 & 79.6 & 135.8 & 245.5 & 356.3 & 120.0 & 180.0 \\
\cline { 2 - 8 } & 6 & 118.4 & 213.0 & 238.4 & 380.1 & 70.0 & 105.0 \\
\cline { 2 - 8 } & 7 & 103.0 & 170.3 & 203.7 & 363.4 & 84.7 & 173.0 \\
\hline & 1 & 41.4 & 65.7 & 114.4 & 196.7 & 67.3 & 126.6 \\
\hline
\end{tabular}




\begin{tabular}{|c|c|c|c|c|c|c|c|}
\hline & 2 & 40.7 & 72.8 & 113.6 & 188.5 & 70.6 & 135.4 \\
\cline { 2 - 8 } & 3 & 45.9 & 81.8 & 125.0 & 194.4 & 82.7 & 144.8 \\
\cline { 2 - 8 } & 4 & 43.6 & 89.8 & 132.2 & 211.5 & 68.3 & 138.0 \\
\cline { 2 - 8 } & 5 & 19.24 & 25.012 & 39.24 & 51.012 & 31.4 & 37.68 \\
\cline { 2 - 8 } 1000 & 6 & 14.0 & 25.3 & 35.0 & 63.0 & 32.8 & 59.8 \\
\cline { 2 - 8 } Capacity & 7 & 34.1 & 60.1 & 93.2 & 150.9 & 58.8 & 107.1 \\
\hline
\end{tabular}

Table 7 presents 1170 lux samples in daily average.

Table 7. Daily daylight contribution for each building using random method.

\begin{tabular}{|c|c|c|c|c|c|c|c|}
\hline \multirow{2}{*}{ Building } & \multirow{2}{*}{ Day } & $\begin{array}{l}\text { Window } \\
\text { closed }\end{array}$ & $\begin{array}{c}\text { Window } \\
\text { open }\end{array}$ & $\begin{array}{l}\text { Window } \\
\text { closed }\end{array}$ & Window open & $\begin{array}{c}\text { Window } \\
\text { closed }\end{array}$ & $\begin{array}{l}\text { Window } \\
\text { open }\end{array}$ \\
\hline & & \multicolumn{2}{|c|}{ Morning average lux level } & \multicolumn{2}{|c|}{$\begin{array}{c}\text { Afternoon average lux } \\
\text { level }\end{array}$} & \multicolumn{2}{|c|}{ Evening average lux level } \\
\hline \multirow{7}{*}{3 in $1 \mathrm{~A}$} & 1 & 180.1 & 398.0 & 195.4 & 347.6 & 111.2 & 274.0 \\
\hline & 2 & 172.9 & 379.2 & 295.4 & 494.6 & 129.7 & 259.9 \\
\hline & 3 & 121.3 & 228.0 & 223.4 & 355.6 & 153.9 & 249.8 \\
\hline & 4 & 102.4 & 132.4 & 175.9 & 296.3 & 94.8 & 146.7 \\
\hline & 5 & 201.3 & 422.8 & 310.3 & 507.2 & 168.7 & 354.2 \\
\hline & 6 & 90.0 & 177.7 & 242.6 & 373.4 & 310.2 & 651.5 \\
\hline & 7 & 144.7 & 289.7 & 240.5 & 395.8 & 161.4 & 322.7 \\
\hline \multirow{7}{*}{ FBN } & 1 & 60.7 & 99.8 & 90.2 & 152.8 & 114.4 & 250.9 \\
\hline & 2 & 77.4 & 113.1 & 111.2 & 116.2 & 73.1 & 88.8 \\
\hline & 3 & 69.4 & 75.5 & 106.1 & 107.7 & 138.9 & 256.6 \\
\hline & 4 & 88.6 & 127.1 & 124.5 & 128.4 & 131.7 & 237.7 \\
\hline & 5 & 79.6 & 135.8 & 245.5 & 356.3 & 120.0 & 180.0 \\
\hline & 6 & 14.0 & 25.3 & 35.0 & 63.0 & 32.8 & 59.8 \\
\hline & 7 & 65.0 & 96.1 & 118.8 & 154.1 & 101.8 & 178.9 \\
\hline \multirow{7}{*}{$\begin{array}{c}1000 \\
\text { Capacity }\end{array}$} & 1 & 37.8 & 63.1 & 102.9 & 182.7 & 62.5 & 125.0 \\
\hline & 2 & 38.7 & 67.3 & 104.8 & 174.2 & 64.6 & 130.7 \\
\hline & 3 & 44.7 & 76.3 & 114.8 & 173.1 & 87.3 & 145.9 \\
\hline & 4 & 42.4 & 88.4 & 122.5 & 197.4 & 63.4 & 136.3 \\
\hline & 5 & 25.2 & 32.7 & 45.8 & 59.6 & 36.6 & 44.0 \\
\hline & 6 & 12.3 & 22.1 & 32.9 & 59.2 & 56.8 & 103.8 \\
\hline & 7 & 33.5 & 58.3 & 87.3 & 141.0 & 61.9 & 114.3 \\
\hline
\end{tabular}

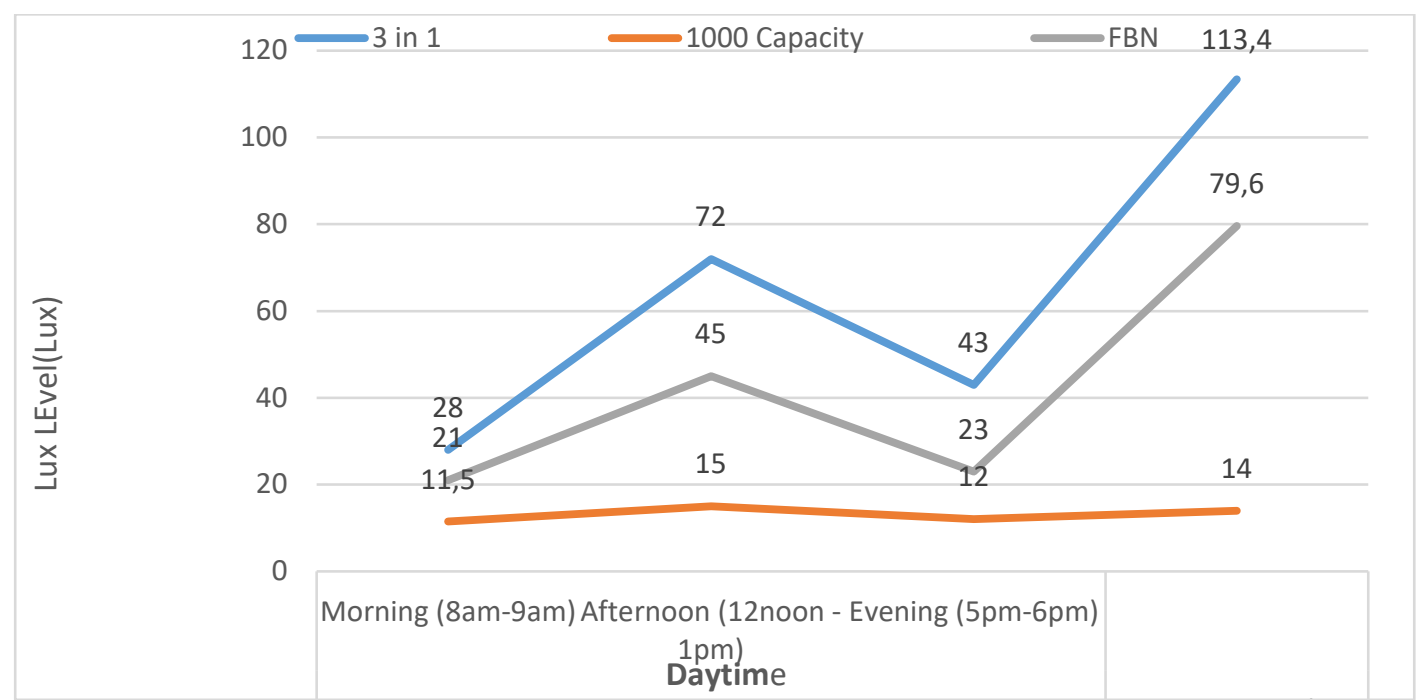

Fig. 10. Least Vs Average Lux Level for Room Index Method. 
Figure 9 shows the window area to wall area ratio of the buildings, 3 in 1 building has the highest window area to wall area of 37 , FBN has $22.2 \%$ window area to wall area and $13.9 \%$ for 1000 capacity. From Table 3, the room index of the buildings is from 7.2 to 15.7 which is greater than three the minimum measuring point was 25 according to Table 2. From Figure 1, the daylight contribution varies from 12 lux to 3803 lux.

From Table 4, the random method was also used to determine the points of lux level measurement based on the sitting arrangement of the building. From Table 5, the daylight contribution varies from 12 lux to 3803 lux. Table 6 shows the average daily daylight contribution for each building using room index method which varies from 113 lux to 1352 lux for 3-in-1 building, 80 to 380 for FBN building and 14 to 194 for 1000 capacity. Table 7 shows the average daily daylight contribution for each building using random method, the average lux level varies from 90 to 495 for 3-in-1 building, 14 to 356 for FBN and 12 to 197 for 1000 capacity. There is difference in lux level for both methods. It therefore means that since RI method is scientific unlike un-scientific random method which cannot be reliable in daily daylight lux contribution in this research.

From Figure 10, the least lux varies from 12, 21 to 28 lux in 3150 point samples, and minimum average lux level varies from 14, 80 to 113 lux in 42 daily average samples. The lux of 12 is considered poor for lecture activities while 21 and 28 lux samples is moderate and more adequate respectively for lecture activities. For the average lux level, 14 is poor for lecture activities while 80 and 113 lux is moderate and more adequate respectively for lecture activities.

From both Figures, 3 -in-1 building as the highest values follow by FBN and 1000 capacity as the least. This corresponds the window area to wall area ratio pattern of $37 \%, 22 \%$ and $14 \%$ for 3 -in- 1, FBN and 1000 capacity respectively. This means that the higher the window area to wall area the better the daylight contribution. FBN and 1000 capacity window area to wall area ratio does not conform with the existing literature of $25 \%$. However, the $\quad 22 \%$ of FBN in this work is adequate for lecture theater while $14 \%$ of 1000 capacity is not suitable for lecture because reading and writing in this hall is poor. Meanwhile $37 \%$ of 3 -in- 1 is adequately suitable for lecture.

\section{CONCLUSIONS AND RECOMMENDATIONS}

\subsection{Conclusions}

The followings conclusions are made in this work.

i. The room index method is reliable;

ii. The daylight contribution(DLC) varies from 12 to 3803 lux;

iii. $\quad 22 \%$ window area to wall area is considered moderate;

iv. $\quad 37 \%$ window area to wall area is considered more suitable;

v. The daylight contribution is a function of light entering the interior of building;

vi. The DLC is essential for lighting energy reduction in lecture theatre.

\subsection{Recommendations}

Daylight contribution should be implored in electrical lighting design in order to optimize daylight contributions and reduce non-renewable electricity cost. The building designer should design window to wall ratio of least 22 $\%$ minimum, for moderate daylight contribution for a lecture theatre.

\section{REFERENCES}

[1] Badri, N.M., Kumar, R., Sushant, K.M., Analysis of daylighting using daylight factor and luminance for different room scenarios. International Journal of Civil Engineering and Technology. vol. 9, 2018, p. 949-960.

[2] Gwaivangmin, B., The impact of daylighting in the development of sustainable electric power and building infrastructures in Nigeria. Continental Journal of Engineering sciences, vol. 11, 2016, p. 42 - 52.

[3] Edward, M. D. Daylighting Designs in Libraries. Retrieved from www.librisdesign.org Science.

[4] Mahmoud, O., Investigation of the daylighting and the thermal environment of Nigeria's low-income housing. retrieved from https://www.google.com/search?client=opera\&hs\&ei=wMg6X8Z9GYTfxgP8mqvACA\&q=Mahmoud. 
[5] Ullah, I., Daylight for healthy indoor environment and energy benefits. International journal of ophthalmology an eye, vol. 2, 2014, p. 1-2.

[6] Intergovernmental panel on climate change, IPCC, The physical science basis. retrieved from https://www.ipcc.ch/site/assets/uploads/2017/09/WG1AR5_Frontmatter_FINAL.pdf AC, 2013 (accessed 14 April 2020).

[7] Motamedi, S., Energy analysis of toplighting strategies for office buildings in Austin (Dissertation), University of Texas, Austin, 2012.

[8] Mahdavinejad, M., Mohammadi, S., Parametric optimization of daylight and thermal Performance through louvers in hot and dry climate of Tehran, Journal of fundamental and applied sciences, 8, 2018, p. 1221-1236.

[9] Fasi, M., Budaiwi, I., Energy performance of windows in office buildings considering daylight integration and visual comfort in hot climates, Energy build, Retrieved from https://www.tib.eu/en/search/id/elsevier\%3Adoi 10.1016\%252Fj.enbuild.

[10] $\mathrm{Wu}, \mathrm{G} .$, Studies in preliminary design of fenestration: Balancing daylight harvesting and energy consumption.retrieved from https://www.semanticscholar.org/paper.

[11] Sergio, A., Daylight for energy savings and psycho-physiological well-being in Sustainable built environments, Journal of sustainable development, vol. 1, 2008, p. 3-16.

[12] Ihm, P., Nemri, A., Krarti, M., Estimation of lighting energy savings from daylighting. Retrieved from www.elsevier.com/locate/buildenv, 2009.

[13] Dubois, M.C., Blomsterberg, A., Energy saving potential and strategies for electric lighting in future North European, low energy office buildings: A literature review, Energy Build, vol. 43, 2011, p. 2572-2582.

[14] Imessad, K., Derradji, L., Messaoudene, N.A., Mokhtari, F., Chenak, A., Kharchi, R., Impact of passive cooling techniques on energy demand for residential buildings in a mediterranean climate, renewable energy journal, vol. 7, no. 2, 2014, p. 589-597.

[15] Santamouris, M., Asimakopoulos, D., Passive cooling of buildings, Publisher, Earthscan, 2013. Retrieved from https://books.google.com.ng/books.

[16] Intergovernmental panel on climate change, IPCC, Impacts, adaptation and vulnerability, 2014, Retrieved from https://archive.ipcc.ch/pdf/assessment-report/ar5/wg2/WGIIAR5-FrontMatterA_FINAL.pdf, 2014 (assess, 14. April, 2020).

[17] Buhari, A.A., Alibaba, H.Z., Analysis of daylighting quality in institutional libraries, International Journal of electrical and Electronics Research. vol. 7, no. 4, 2019, p. 6-20.

[18] Ayoosu, M.L., Lim, Y.W., Leng, P.C., Daylighting performance assessment of side-lit university lecture theatres in the hot-humid climate of Makurdi in Nigeria, International journal of recent technology and Engineering, vol. 8, no. 5, p. 4584-4589.

[19] Afolami, A.J., Aluko, O.O., Adegbie, M.O., Evaluation of daylight levels in an Administrative building in Akure, Nigeria, Journal of Environmental Management and Safety, vol. 4, 2013, p. 18-34.

[20] Huang, X., Shangyou, W.E., Shangyu, Z., Study on Daylighting Optimization in the Exhibition Halls of Museums for Chinese Calligraphy and Painting Works Energies, Retrieved from www.mdpi.com/journal/energies, 2020.

[21] Heschong, L., Wymelenberg, V.D., Andersen, M., Digert, N., Fernandes, L., Keller, A., Loveland, J., Mckay, H., Mistrick, R., Mosher, B., Approved Method: IES spatial daylight Autonomy (SDA) and Annual sunlight exposure (ASE). Retrieved from https://infoscience.epfl.ch/record/196436? ln=e.

[22] Pinilla, S.M., Moliní, D.V., Fernandez-Balbuena, A.A., Raboso, G.H., Herraez, J.A., Azcutia, M., Botella, A. G., Advanced daylighting evaluation applied to cultural heritage buildings and museums: Application to the cloister of Santa Maria El Paular, Renew Energy, vol. 85, 2016, p. 1362-1370.

[23] Wonuk, K, Yongseok, J., Yongchan K., Simulation-based optimization of an integrated daylighting and HVAC system using the design of experiments method. Applied energy, Elsevier, vol. 162, 2016, p. 666-674.

[24] Sadineni, S., Madala, S., Boehm, R., Passive building energy savings: A review of building envelope components. Renewable and sustainable energy reviews, Elsevier, vol. 15, 2011, p. 3617-3631.

[25] Vishwas, M., Soori, P.K., Simple tool for energy analysis of day lighting and artificial lighting for a typical office building lighting system design, International journal of energy engineering, vol. 2, no, 6, 2012, p. 332-338.

[26] Oyeleye, M.O., Illumination evaluation of lecture theatre, case study of 1000 seat lecture theatre, federal university of technology, Akure, Nigeria. European journal of engineering research and science, vol. 4, no. 7, 2019, p. 31-36.

[27] Philips, C.D., Science and art and daylighting bringing naturalization. Retrieved from www.ndri.ir/Sites/Files/261/DayLighting.pdf, 2013.

[28] Brown, G., Dekay, M., Sun, wind and light: architectural design strategies. Retrieved from https://www.wiley.com, 2014. 
[29] Bennett, K.M., Light in architecture: natural and artificial lighting techniques that brighten our sacred spaces (dissertation). University of Utah, Salt Lake City, Utah, 2008.

[30] Dean, E.T., Daylighting design in libraries. Retrieved from www.librisdesign.org, 2005, (assess 4, April, 2020).

[31] Lechner, N., Heating, cooling, lighting: sustainable design methods for architects. Retrieved from https://www.worldcat.org/title/heating-cooling-lighting-sustainable-design-methods-for-

architects/oclc/867423820, 2015, (assess 14, April 2020).

[32] Weather spark, average weather in Akure. Retrieved from https:// weatherspark.com, 2020, (assess 14, April, 2020).

[33] Oyeleye, M.O., Akanni, S.A., Evaluation of lux level adequacy: case study of school of engineering, federal university of technology, Akure. International journal of science and engineering investigations, vol. 8, no. 80, 2019, p. 74-79.

[34] Nikpour, M., Kandar, M.Z., Sulaimani, M.S., Rashid, Y.R., Ossen, D.R., Mabdullah, A., Wah, L.Y., Investigating daylight quality in Malaysian government office buildings through daylight factor and surface luminance, International Journal of civil and environmental engineering, vol. 5, no. 11, 2011, p. 589-594. 